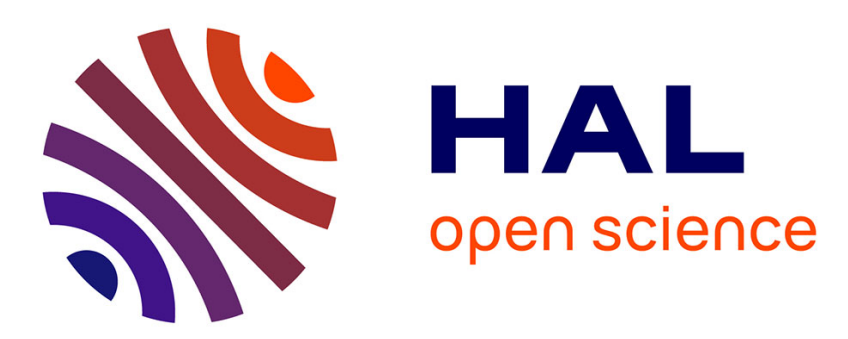

\title{
Agronomic and physiological performances of different species of Miscanthus, a major energy crop. A review
}

\author{
H. W. Zub, M. Brancourt-Hulmel
}

\section{To cite this version:}

H. W. Zub, M. Brancourt-Hulmel. Agronomic and physiological performances of different species of Miscanthus, a major energy crop. A review. Agronomy for Sustainable Development, 2010, 30 (2), 10.1051/agro/2009034. hal-00886516

\section{HAL Id: hal-00886516 https://hal.science/hal-00886516}

Submitted on 1 Jan 2010

HAL is a multi-disciplinary open access archive for the deposit and dissemination of scientific research documents, whether they are published or not. The documents may come from teaching and research institutions in France or abroad, or from public or private research centers.
L'archive ouverte pluridisciplinaire HAL, est destinée au dépôt et à la diffusion de documents scientifiques de niveau recherche, publiés ou non, émanant des établissements d'enseignement et de recherche français ou étrangers, des laboratoires publics ou privés. 


\title{
Review article
}

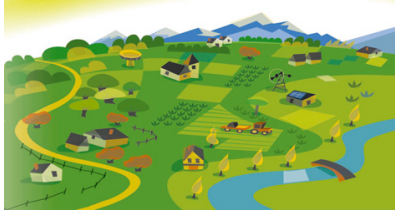

\section{Agronomic and physiological performances of different species of Miscanthus, a major energy crop. A review}

\author{
H.W. ZUB, M. BRANCOURT-HULMEL* \\ INRA, USTL UMR 1281, 80203 Estrees-Mons, Peronne, France
}

(Accepted 16 September 2009)

\begin{abstract}
The European Union recommends the use of lignocellulosic biomass to produce biofuels in order to reduce greenhouse gas emissions. Miscanthus $\times$ giganteus, $\mathrm{a} \mathrm{C}_{4}$ perennial and rhizomatous plant, has been identified as a good candidate for biomass production because of its high potential yield, of up to $49 \mathrm{t} \mathrm{DM.ha}{ }^{-1}$ for autumn harvest and $26 \mathrm{t} \mathrm{DM.ha}{ }^{-1}$ for winter harvest, under low input levels. Here, we review current knowledge on the biomass production in Europe of $M \times$ giganteus and its two parental species, M. sinensis and M. sacchariflorus, under different stress conditions. This review identifies two key areas where $M$. giganteus crops could be improved: (i) tolerance to frost during winter or early spring is essential, mainly in Northern Europe, in order to ensure overwintering and protect young shoots following early emergence. Susceptibility to winter frost at temperatures below $-3.5^{\circ} \mathrm{C}$ for rhizomes and $-8{ }^{\circ} \mathrm{C}$ for young shoots of $M$. $\times$ giganteus can lead to significant plant losses and lower yields, and (ii) a good water supply is necessary to ensure good establishment rates and satisfactory biomass production. Reductions of up to $84 \%$ in above-ground dry matter production because of a lack of water for the autumn harvest, and up to $26 \%$ for the winter harvest have been observed. M. sinensis, which displays greater genetic variability than M. giganteus, will provide the necessary genetic resources for frost and water stress tolerance. It is also necessary to either identify genotypes among $M$. sinensis species that are able to produce an above-ground biomass yield close to the biomass production of $M$. giganteus under limited water supplies and/or low temperatures, or to generate new interspecific hybrids of $M$. giganteus with greater tolerance. Particular attention should be paid to nitrogen response; although no response to nitrogen supply has been observed in M. giganteus, M. sinensis produces higher levels of biomass with nitrogen inputs.
\end{abstract}

Miscanthus / biomass production / chilling temperature / frost / nitrogen supply / water supply / improvement

Abbreviations: DM, dry matter; WUE, water-use efficiency; NUE, nitrogen-use efficiency; RUE, radiation-use efficiency

\section{Contents}

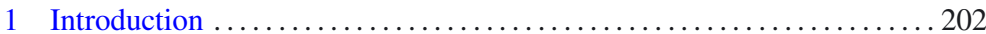

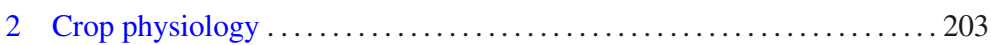

2.1 Principal features of a miscanthus crop ................ 203

2.2 Threshold temperature for emergence and thermal time for the growth and development of a miscanthus crop ......................... 203

2.3 Radiation-, water- and nitrogen-use efficiencies ............... 205

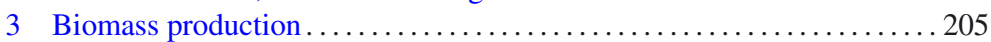

3.1 Potential for biomass production by different species ......... 205

3.2 Components of above-ground biomass $\ldots \ldots \ldots \ldots \ldots \ldots \ldots \ldots 206$

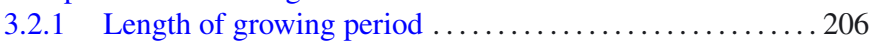

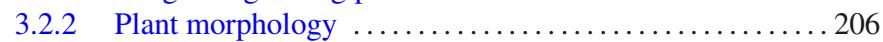

4 Response of miscanthus to stress conditions ................... 207

4.1 Effect of chilling temperatures $\ldots \ldots \ldots \ldots \ldots \ldots \ldots \ldots \ldots \ldots \ldots \ldots \ldots$

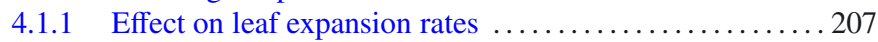

4.1.2 Effect on light interception and photosynthesis ......... 207

*Corresponding author: brancour@mons.inra.fr 


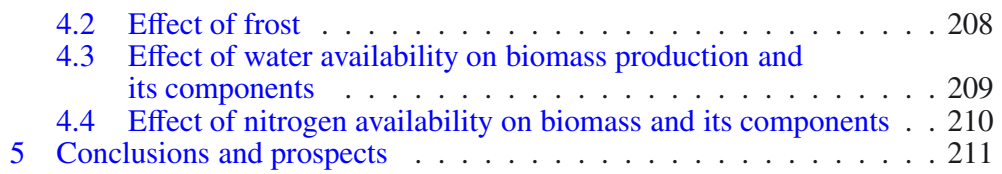

\section{INTRODUCTION}

Energy security and imperatives related to climate change require the large-scale substitution of petroleum-based fuel. Plant-based biofuels will achieve a reduction in greenhouse gas emissions through the fixation of atmospheric carbon in useful biomass (Ceotto, 2008) and the sequestration of carbon in the soil (Benbi and Brar, 2009). European Directive 2003/30/EC promoted the use of renewable sources by defining targets for biofuels in 2010: 5.75\% of the fuel consumed in Europe should be produced from biomass. As ethanol production in France, this corresponds to about $2.5 \%$ of the total land planted to cereals to enable its production from conventional crops such as sugarbeet and winter wheat (Gurtler, 2007). To reduce this proportion, new "dedicated" energy crops are of particular interest for the production of biofuel using lignocelluloses, a structural material that accounts for much of the mass of plants. One of the benefits of lignocellulosic biofuel is that it reduces greenhouse gas emissions by $85 \%$ compared with reformulated gasoline (Wang et al., 2007). Crutzen et al. (2008) found that ethanol produced from corn and sugarcane had a "net climate warming" effect when compared with oil. Another advantage of lignocellolosic biomass is that it can be produced from abundant and diverse raw materials such as wood, grasses or the non-edible parts of plants. Among these different raw materials, a good candidate is miscanthus, a tall, perennial, rhizomatous $\mathrm{C}_{4}$ grass of the Poaceae Family (Hastings et al., 2008). It produces a large quantity of biomass under low input levels (Clifton-Brown et al., 2004). Its tropical and subtropical genotypes grow to 3 to $4 \mathrm{~m}$ when cultivated in Europe, and more in the warm and wet climates of southeast Asia (Fig. 1). Miscanthus rhizomes, or micro-plants, are planted in spring and the canes produced during the summer are harvested annually during the late autumn or winter, following the second or third growing season of the crop. The lifetime of the crop varies from 20 to 25 years (Lewandowski et al., 2003), and the long-term Miscanthus plantations enhance soil carbon sequestration (Hansen et al., 2004). Miscanthus spreads naturally via its underground storage organs or rhizomes, but some species can also be seed-propagated. Because miscanthus is propagated vegetatively, the clone is the variety type.

The cultivation of miscanthus in Europe is mainly based on one species, M. giganteus, which is a natural triploid hybrid between a diploid M. sinensis and a tetraploid M. sacchariflorus (Greef and Deuter, 1993; Linde-Laursen, 1993). M. giganteus production is characterised by low input levels, so that it is a relatively environmentally-friendly crop (Lewandowski et al., 2000). To date, no susceptibility to diseases or pests has been reported by the authorities in the UK (DEFRA, 2007), the European country where the crop is most widely cultivated.

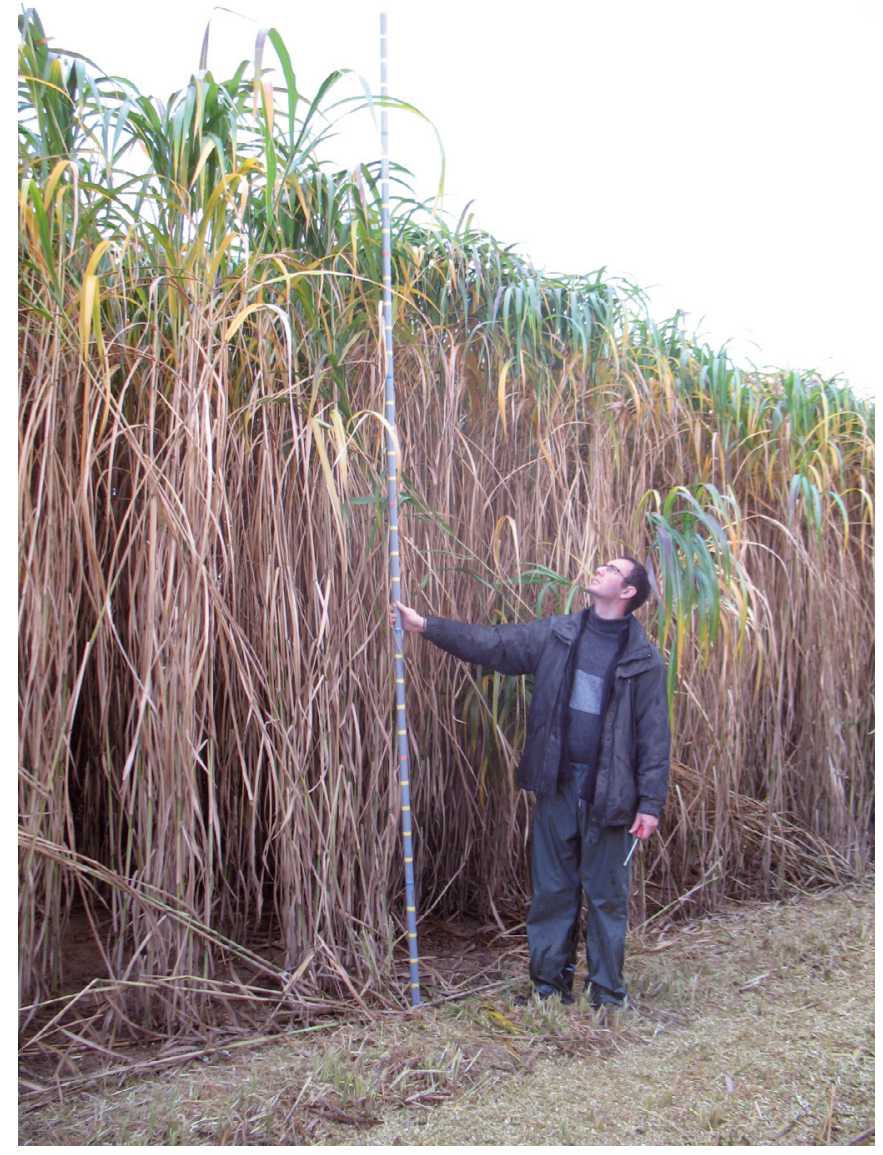

Figure 1. Miscanthus $\times$ giganteus during the third year of growth at Estrees-Mons, France (๑ INRA Lille).

The principal limitations to miscanthus production from M. giganteus are its high establishment costs, its poor overwintering at some sites and the insufficient water supplies available in southern regions of Europe. M. giganteus has been found to display very little genetic diversity because of its sterility and vegetative propagation. Most of the clones found in this species were descended directly from the 'Aksel Olsen' clone, as shown by isozyme and DNA studies (Vonwuhlisch et al., 1994; Hodkinson et al., 2002). The only exception may be the 'Hervey' clone that came from Japan to the UK in the 1980s (Greef et al., 1997). The small genetic base of M. giganteus explains why the same clone has nearly always been used during agronomy studies or for cultivation. The sterility of M. giganteus is particularly interesting because it prevents putative invasion by the species; on the other hand, it is an issue in terms of improving biomass production and adapting it to a broad range of climatic conditions. Nevertheless, 
the Miscanthus genus contains more than 20 species, most of them originating from a broad range of geographic regions in Asia, from the sub-tropics to sub-arctic conditions (Numata, 1974, cited by Clifton-Brown and Lewandowski, 2002). Furthermore, the genetic diversity of the M. sinensis pool is relatively high compared with $M$. giganteus accessions (Greef et al., 1997). M. sinensis is described as being self-incompatible (Greef and Deuter, 1993), which facilitates crossing and genetic studies; it can therefore be exploited to improve its resistance to abiotic factors or its industrial properties.

In order to highlight the need for research on the adaptation of miscanthus to European conditions, the present paper reviews the agronomic and physiological performance, and response to various stresses, of different Miscanthus that could be used to produce biomass in Europe. It focuses on the three species studied in Europe: $M$. giganteus, $M$. sinensis and M. sacchariflorus. Stress conditions result from an excess or deficit in a physical or chemical environment. The environmental conditions that affect plant growth include high or low temperatures, excess rainfall, drought, or inadequate soil mineral nutrients such as nitrogen. Depending on when these environmental factors occur, their intensity and duration can reduce plant vitality and cause damage. The paper is presented in two sections; the first is devoted to a description of the plant, with particular emphasis on its agronomic potential and the variations affecting the production of biomass production by different Miscanthus species, while the second concerns the influence of stress conditions on plant traits.

\section{CROP PHYSIOLOGY}

Most agronomic and physiological research has focused on one clone of $M$. giganteus. This section describes the life cycle of miscanthus, its requirements for establishment and growth and the efficiencies of the crop in terms of radiation, water and nitrogen $(\mathrm{N})$ use. References to $M$. sinensis or M. sacchariflorus are mentioned when available.

\subsection{Principal features of a miscanthus crop}

To establish a crop, the optimum planting date is dependent on the plant material. Whereas rhizomes can be planted from March to May (depending on the climate), micro-plants or plants established in pots should be planted later (late AprilMay) in order to avoid late frosts and improve establishment rates (Christian and Haase, 2001). In general, the irrigation of newly-planted rhizomes seems to improve the establishment rate under drier conditions, particularly in Southern Europe. Because of the high production cost of rhizomes or microplants, the optimum crop density is very low as the plant is able to produce several stems. The usual density is 2 plants. $\mathrm{m}^{-2}$, but this can be increased to 5 plants. $\mathrm{m}^{-2}$, the level studied in Europe (Lewandowski et al., 2000). However, Christian et al. (2009) recommended planting at least $14 \%$ extra rhizome fragments when using 5-year-old rhizomes in order to attain the required plant density.
After emergence, tillering, or the number of productive shoots per plant, increases rapidly during May, June and July (e.g. up to 40 stems.plant $^{-1}$ for $M$. giganteus during a UK experiment) (Bullard et al., 1997). Rhizome-propagated plants may have fewer but stronger shoots than micropropagated plants (Lewandowski, 1998). During the growing period, the number of productive shoots falls to 25 stems.plant $^{-1}$. This phenomenon can be compared to tillering regression in wheat, barley or forage grasses (Aspinall, 1961; Thorne, 1962; Gillet, 1980). The youngest tillers decline while the oldest continue to grow in August, September or even October, depending on the climate and time elapsing between emergence and flowering.

During the growing period, leaf area development follows a rapid, one-peak curve. In the second year following establishment, it reaches a maximum leaf area index (LAI) of 6-10, depending on treatments and climate. Maximum LAI values have been observed during the flowering phase, after which the canopy starts to senesce (Cosentino et al., 2007). A mature stand of M. giganteus is able to intercept around $90 \%$ of useful photosynthetic radiation when the LAI reaches 3.2 (Clifton-Brown et al., 2000). A similar value was found for M. sinensis Goliath (Vargas et al., 2002). The light extinction coefficient $(\mathrm{k})$ through the leaf cover of the crop provides a measurement of the absorption of light by leaves: M. giganteus achieves between 0.56 and 0.68 according to some authors (Cosentino et al., 2007; Clifton-Brown et al., 2000, respectively), whereas $M$. sinensis Goliath reaches 0.66 (Vargas et al., 2002). Most of these values are close to that of 0.67 reported for maize (Clifton-Brown and Jones, 1997).

The end of the growing period coincides with a drop in temperatures, and full senescence can occur with the first frost, as observed in the autumn in Denmark (Christian and Haase, 2001). However, the oldest leaves towards the base of stems start to senesce earlier. At the end of the growing season, nutrients and photosynthates are remobilised from the stems and leaves to the rhizomes (Christian and Haase, 2001). In $M$. sinensis, this accumulation is synchronised with flowering from July to October, depending on the genotype (Stewart et al., 2009). All stems left standing gradually dry out during the winter, until February/March when the crop is ready for winter harvest.

\subsection{Threshold temperature for emergence and thermal time for the growth and development of a miscanthus crop}

The threshold temperature corresponds to the temperature at which the plant can start to grow. Thermal time, which is the cumulated value of degree-days from emergence to flowering time, is often used in crop physiology to estimate or predict the length of different developmental phases under cultivated conditions. The degree-day is a function of baseline temperature. For Miscanthus, the threshold and baseline temperatures vary between studies (Clifton-Brown and Jones, 1997; Farrell et al., 2006).

Clifton-Brown and Jones (1997) demonstrated the growth of shoots in a controlled environment at temperatures between 
$6{ }^{\circ} \mathrm{C}$ and $20{ }^{\circ} \mathrm{C}$, although the extension rate was lower at $6{ }^{\circ} \mathrm{C}$ than at $15{ }^{\circ} \mathrm{C}$ or $20{ }^{\circ} \mathrm{C}$. Price et al. (2004) concluded that the threshold temperature for growth was $6{ }^{\circ} \mathrm{C}$ because M. giganteus could grow at this temperature. When comparing different species, Koike et al. (1975) cited by Stewart et al. (2009) observed that a daily mean air temperature of $7{ }^{\circ} \mathrm{C}$ was necessary to initiate growth of the above-ground organs of M. sinensis. Farrell et al. (2006) studied the effect of temperature on shoot emergence in four miscanthus genotypes: a clone of M. sacchariflorus, a clone of M. giganteus and two hybrids of M. sinensis. Shoot production was markedly influenced by temperature in all genotypes. The rate of emergence increased in line with temperature (Tab. I). Genotypes with a lower threshold temperature for emergence were thus able to emerge earlier. Similarly, the thermal responses for emergence in M. giganteus and M. sacchariflorus (slope of regression fits of 0.01 and 0.008 , respectively) were lower than those of M. sinensis hybrids (between 0.011 and 0.014 ). Higher emergence rates were associated with both a shorter thermal requirement for emergence and earlier emergence. Farrell et al. concluded as to the existence of genetic variability regarding the threshold temperature required for emergence. Hybrids of $M$. sinensis had a lower threshold temperature for emergence than M. giganteus and M. sacchariflorus (Tab. I).

Both Clifton-Brown et al. (2000 and 2004) and Hastings et al. (2008) preferred to use $10^{\circ} \mathrm{C}$ as the baseline temperature in their model to predict potential yield without water stress (Clifton-Brown et al., 2000) or under water stress (Hastings et al., 2008). Indeed, Clifton-Brown et al. (2000) showed a better correlation between cumulative degree-days and leaf area index using a threshold temperature of $10^{\circ} \mathrm{C}$ rather than $6^{\circ} \mathrm{C}$. It is necessary to carry out similar experiments with M. sinensis in order to determine the threshold temperature and thus compare the thermal times of different Miscanthus crops.

Applying a threshold temperature of $10{ }^{\circ} \mathrm{C}$ for three species, the thermal time required to reach peak heading time was estimated at around $900{ }^{\circ} \mathrm{C}$ for $M$. sinensis grasses in Japan (Shoji et al., 1990). According to Lewandowski and Clifton-Brown (2000), a thermal time of $1800{ }^{\circ} \mathrm{C}$ accurately predicted the time for flowering of the only $M . \times$ giganteus clone studied in Europe. Numata and Mitsudera (1969) cited by Stewart et al. (2009) reported a thermal time of $1500-4000{ }^{\circ} \mathrm{C}$ for the flowering of $M$. sinensis grasses in Japan, and this was equivalent to a vegetative growth period of 6-9 months. Although one study with several M. sinensis genotypes was carried out at five sites in Europe (CliftonBrown et al., 2001a), no data are available on the variations in the thermal time for growth of this species in Europe.

Clifton-Brown et al. (2001a) observed variations in flowering date among genotypes and across countries. The induction of the flowering is dependent on day length and variations are observed among the species. These can be related to the geographical origin of genotypes (Lewandowski et al., 2003). Experiments under artificial light conditions have been carried out to induce flowering. A short-day light period may be necessary to induce the flowering of M. sacchariflorus (Deuter, 2000). By contrast, day length may be less important than cumulative degree-days in M. sinensis. For instance, a particular

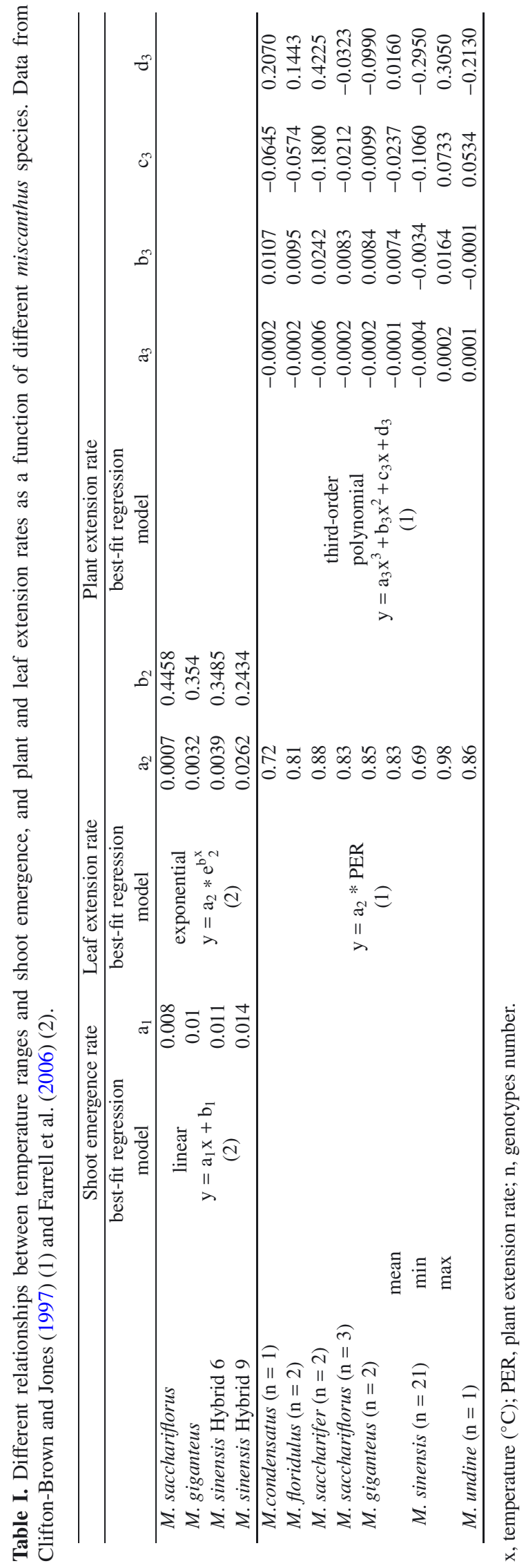


genotype of $M$. sinensis flowers earlier in Portugal than in Sweden because it receives its sum of degree-days for flowering more rapidly (Clifton-Brown et al., 2001a).

\subsection{Radiation-, water- and nitrogen-use efficiencies}

Because of its $\mathrm{C}_{4}$ photosynthetic pathway and perennial rhizome, miscanthus displays quite a good combination of radiation-, water- and nitrogen-use efficiencies for biomass production (Lewandowski et al., 2000; Heaton et al., 2004; Lewandowski and Schmidt, 2006). Several studies have been carried out to determine these efficiencies in one clone of M. giganteus, and genetic variability has been reported with respect to the radiation- and water-use efficiencies of other Miscanthus species.

A linear relationship was found for miscanthus between cumulated above-ground dry biomass (or dry matter, DM) and global intercepted solar radiation (Clifton-Brown et al., 2000). Under water and nitrogen supplies, the radiation-use efficiency (RUE) of $M$. giganteus reached $4.1 \mathrm{~g} \mathrm{DM} . \mathrm{MJ}^{-1}$ in France and the USA (Tayot et al., 1995; Heaton et al., 2008). Lower values

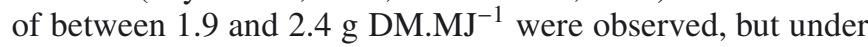
conditions of water stress (Bullard et al., 1997; Price et al., 2004; Clifton-Brown et al., 2000) or using a different method to calculate RUE values (Cosentino et al., 2007).

As for water-use efficiency (WUE), studies showed that an adult $M$. giganteus stand reached between 9.1 and $9.5 \mathrm{~g} \mathrm{DM}^{-1} \mathrm{1}^{-1}$ in the UK (Beale et al., 1999) and between 6 and $10 \mathrm{~g} \mathrm{DM} . \mathrm{I}^{-1}$ in France (Cadoux et al., 2008). Lower values were found in a Mediterranean environment, with a negative correlation of -0.87 between water availability and WUE (Cosentino et al., 2007). Beale et al. (1999) showed that irrigation during dry periods reduced the WUE of the crop by $15 \%$, with a higher water consumption of $45 \%$.

The average nitrogen-use efficiency (NUE) of aboveground $M$. giganteus biomass was calculated at about $277 \mathrm{~kg} \mathrm{DM} . \mathrm{kg}^{-1}$ of the N supply (total available nitrogen including soil $\mathrm{N}$ and $\mathrm{N}$ supply not being evaluated), but considerable variability was observed, ranging from $143 \mathrm{~kg} \mathrm{DM} . \mathrm{kg}^{-1}$ in Ireland to $613 \mathrm{~kg} \mathrm{DM} \cdot \mathrm{kg}^{-1}$ in Portugal (Christian and Haase, 2001). The NUE calculated from the increase in biomass at different $\mathrm{N}$ input levels decreased continuously with an increasing $\mathrm{N}$ supply (Lewandowski and Schmidt, 2006; Cosentino et al., 2007). Furthermore, a $9 \%$ reduction in NUE was observed with an increase in the water supply (Cosentino et al., 2007).

Genotypic variability has been studied with respect to RUE and WUE, but not NUE. In field conditions under nitrogen supply and without irrigation, Jorgensen et al. (2003a) and Vargas et al. (2002) showed higher RUE values for M. sinensis (average: $1.62 \mathrm{~g} \mathrm{DM} . \mathrm{MJ}^{-1}$ ) than for hybrids between M. sinensis (with an intermediate RUE) and M. sacchariflorus. Under water stress conditions, RUE values for hybrids between $M$. sinensis and $M$. sacchariflorus were close to those of $M$. giganteus. By contrast, under controlled conditions, Clifton-Brown et al. (2000) demonstrated similar WUE values for young shoots of $M$. giganteus and $M$. sinensis ( $\left.2 \mathrm{~g} \mathrm{DM} .1^{-1}\right)$, but the highest value was seen in $M$. sacchariflorus $\left(3.8 \mathrm{~g} \mathrm{DM}^{-1}\right)$.

Several studies comparing the RUE (Beale and Long, 1995; Heaton et al., 2008), NUE (Boehmel et al., 2008; Lewandowski and Schmidt, 2006) and WUE (Beale et al., 1999) of miscanthus with other energy crops concluded as to the superiority of miscanthus efficiencies over other species. Firstly, Beale and Long (1995) and Heaton et al. (2008) found $50 \%$ higher RUE values for Miscanthus giganteus than for two other rhizomatous perennial crops: Spartina cynosuroides and switchgrass. Secondly, Boehmel et al. (2008) compared the nitrogen-use efficiency of different annual and perennial energy cropping systems and concluded that miscanthus had a higher NUE value of $526 \mathrm{~kg}$ DM. kg ${ }^{-1}$ when compared with the NUE of energy maize (65 kg DM. $\left.\mathrm{kg}^{-1}\right)$. Lewandowski and Schmidt et al. (2006) found the same superiority of miscanthus NUE values over Reed canary grass and triticale, which displayed a stronger decrease in NUE values with nitrogen supply than miscanthus. Finally, Beale et al. (1999) showed than Miscanthus had a WUE value that was $35 \%$ to $55 \%$ higher than Spartina cynosuroides as a function of water supply (rainfed and irrigated, respectively).

\section{BIOMASS PRODUCTION}

Because miscanthus is a perennial grass, the first year concerns establishment of the crop, biomass production only being possible during subsequent years. The biomass potential of different species in Europe is discussed first of all, and then the components of this biomass are described.

\subsection{Potential for biomass production by different species}

The lifetime of the crop is estimated at between 20 and 25 years (Lewandowski et al., 2003), during which miscanthus biomass is produced during two phases: a yield-building phase, which in $M$. giganteus lasts for two to five years, depending on climate and plant densities, and a plateau phase where the yield is maintained (Clifton-Brown et al., 2000, 2001b; Christian et al., 2008). Ceiling yields are attained more rapidly in warmer climates than in cooler climates, especially when crop water supplies are not limiting. Trials in southern regions have shown that the plants tend to mature more rapidly than at northern latitudes. The time required to reach the plateau phase is probably species-dependent, but no data are available.

Yield is very low during the first year (less than 10 t.ha $^{-1}$ for $M$. giganteus) but these figures are usually not known as the grass is not harvested. However, yields in the autumn of the first and second years are a good indicator of those for 
the third year. Clifton-Brown et al. (2001a) studied the performance of 15 miscanthus crops belonging to the M. giganteus species (4 clones), M. sacchariflorus (1 clone), M. sinensis species ( 5 clones) and hybrids between M. sacchariflorus and M. sinensis (5 clones), at five sites in Europe during the first three years after establishment and observed a higher and significant correlation of 0.81 between the third-year and secondyear yields, this correlation being 0.56 between the third-year and first-year yields.

During subsequent years, peak yields are obtained in the autumn, at the full plant flowering phase (Cosentino et al., 2007) and then decline through the winter due to leaf loss. Harvestable yields in the spring are $27 \%-50 \%$ lower than in the autumn (Clifton-Brown et al., 2001b; Cadoux et al., 2008; Himken et al., 1997; Jorgensen et al., 2003b; Richter et al., 2008). Jorgensen et al. (2003b) found similar losses of aboveground dry matter yields that reached $40 \%$ and $35 \%$ during the second and third years of growth when harvest was delayed from the autumn to the spring in one M. sacchariflorus, five clones of M. sinensis and five hybrids of $M$. sinensis. Greater above-ground dry matter yield losses were observed for hybrids of M. sinensis than with M. sinensis itself (48\% and 35\%, respectively, during the second year of growth and $45 \%$ and $29 \%$ during the third year of growth; Jorgensen et al., 2003b).

A review of autumn yields in Europe showed that the maxima from $M$. giganteus were obtained in France in Lusignan $\left(44{ }^{\circ} \mathrm{N}, 1{ }^{\circ} \mathrm{E}\right)$ and Grignon $\left(48^{\circ} \mathrm{N}, 2^{\circ} \mathrm{E}\right)$ under irrigated and fertilised conditions: being, respectively, 49 and 42 t DM.ha ${ }^{-1}$ (Clifton-Brown et al., 2004). These yields ranged from 15 to 25 t.ha $^{-1}$ without irrigation. For winter yields of $M$. giganteus, the highest non-irrigated yields were found to be

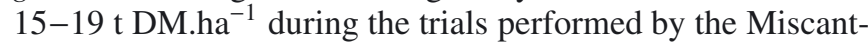
hus Productivity Network that involved 15 European sites.

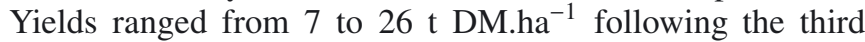
growing season, with some of the trial crops being irrigated (Clifton-Brown et al., 2001b). Outside this network, higher productivity was reported in Central and Southern Europe, but irrigation was always required (Clifton-Brown et al., 2001b; Cadoux et al., 2008).

In order to compare several species, a three-year study was carried out to evaluate the biomass production potential of four acquisitions of $M$. giganteus, one clone of $M$. sacchariflorus, five clones of $M$. sinensis and five hybrids of $M$. sinensis (Clifton-Brown et al., 2001a). During the three years of production, the autumn yields demonstrated the higher productivity of $M$. giganteus when it was able to survive the winter. Apart from $M$. giganteus, higher yields were reported for $M$. sinensis hybrids, the highest being observed in Germany with mean yields of 11.1 tha $^{-1}$ for $M$. sinensis and $15.1 \mathrm{t}^{\mathrm{h}} \mathrm{a}^{-1}$ for hybrids. The mean yields of these hybrids could be between $6 \%$ and $90 \%$ higher than those of $M$. sinensis, depending on the country. Jezowzki (2008) concluded as to the superiority of a hybrid between $M$. sinensis $(2 \times)$ and $M$. sacchariflorus $(4 \times)$ by comparison with a hybrid between $M$. sinensis $(2 \times)$ and $M$. sacchariflorus $(2 \times)$ or between two M. sinensis $(2 \times)$ : mean yields reached $20.5,14.9$ and $9.8 \mathrm{t} \mathrm{DM.ha}{ }^{-1}$, respectively.

\subsection{Components of above-ground biomass}

These differences among genotypes and regions for biomass production could be explained by the difference in the duration of the growing period. Tiller densities, plant height and the proportion of leaves and stems were also key elements explaining the variability in biomass production among species. The next section focuses on above-ground biomass production.

\subsubsection{Length of growing period}

Above-ground biomass production is dependent on the duration of the growth period. After the first year, the start of the growing season is determined by the last spring frost, and the end of the growing season is determined by flowering or the first autumn or winter frost, depending on the harvest date or location.

In European environments, shoot emergence occurs between late March and late April, depending on the climate and the temperature required for the emergence of each genotype (Farrell et al., 2006) (see Sect. 2.2). Because M. sinensis needs fewer cumulative degree-days than M. giganteus and M. sacchariflorus prior to emergence (60 vs. 90 and 120 degree-days, respectively), its growing season starts earlier.

The growing season cycle ranges from 6 to 9 months, depending on the genotype. M. sinensis genotypes, which flower rapidly, display a shorter growing season than hybrids of M. sinensis (which flower later), or M. giganteus, which is generally unable to flower under Northern European conditions (Clifton-Brown et al., 2001a). During the growing season, $M$. sinensis and $M$. giganteus normally produce new stems throughout the vegetation period (Lewandowski et al., 2003; Stewart et al., 2009) while M. sacchariflorus forms about $80 \%$ of its stems in the spring.

\subsubsection{Plant morphology}

Jezowski (2008) studied two M. giganteus, two hybrids of M. sinensis $(2 \times)$ and $M$. sacchariflorus $(2 \times)$, and two hybrids between two M. sinensis. Pooling of their observations revealed a good correlation between yield and shoot numbers and between yield and tuft diameter in 1-year-old plants $(0.78$ and 0.79 , respectively), the mean of productive shoots per plant being 6.6. Stronger correlations were observed during subsequent years (more than 0.90 for 2- and 3-year-old plants; with mean numbers of productive shoots of up to 9.6 and 18.6, respectively), and yield was also correlated with plant height ( 0.67 in the second year and 0.91 in the third year). Angelini et al. (2009) obtained a correlation of 0.75 between stem numbers and the dry yield of above-ground biomass when they pooled their observations on $M . \times$ giganteus over a 10-year period.

Stems make a considerable contribution to above-ground biomass, but this is dependent on harvest date. In M. giganteus, stems constitute between $67 \%$ and $75 \%$ of the standing 
crop biomass in the autumn, depending on crop age (Tayot et al., 1995; Bullard et al., 1997; Ercoli et al., 1999) and up to $77 \%$ or $98 \%$ in the winter, depending on location (Tayot et al., 1995; Cosentino et al., 2007; Christian et al., 2008). In M. sinensis, similar percentages of stems, between 57\% and $78 \%$, have been observed in the autumn (Kalembasa et al., 2005 , Jorgensen et al., 2003b), and up to $94 \%$ in the winter (Jorgensen et al., 2003b).

\section{RESPONSE OF MISCANTHUS TO STRESS CONDITIONS}

Few studies have been devoted to stress conditions, the important one being the European Miscanthus Improvement Project which was designed to broaden the genetic base, test genotypes and develop breeding methods (Lewandowski and Clifton-Brown, 2000). It contributed to developing new screening techniques to determine genotypic variability for traits such as the response to effects of low temperatures, frost tolerance, mineral content and biomass yield (Lewandowski and Clifton-Brown, 2000). This project identified characteristics related to low-temperature growth and frost tolerance as being crucial to the improvement of miscanthus (Jorgensen and Muhs, 2001). Another project, the Miscanthus Productivity Network, studied the limitations of low temperatures and other abiotic factors on the growth of M. giganteus under European climatic conditions (Walsh, 1998).

Studies on the use of environmental resources have focused on the effect of water availability (Christian and Haase, 2001; Clifton-Brown et al., 2002; Cosentino et al., 2007) and nitrogen availability (Lewandowski et al., 1995; Lewandowski and Kicherer, 1997; Lewandowski and Kauter, 2003; Christian et al., 2006; Lewandowski and Schmidt, 2006; Christian et al., 2008).

The effects of cold temperatures and frost are presented first of all, followed by the effects of water and nitrogen availabilities.

\subsection{Effect of chilling temperatures}

Several important air temperature effects on miscanthus growth have been distinguished. Air temperature affects canopy development through organ growth and expansion rates (Clifton-Brown and Jones, 1997; Clifton-Brown et al., 2001b), as well as canopy functioning through photosynthesis (Beale et al., 1996; Weng and Ueng, 1997; Wang et al., 2008a, b).

\subsubsection{Effect on leaf expansion rates}

Thermal responses affecting the leaf expansion rate have been reported with respect to 32 genotypes grown under controlled conditions (Clifton-Brown and Jones, 1997). After the plants were kept in cabinets at $20+/-3{ }^{\circ} \mathrm{C}$ with optimum supplies of water and nutrients, they were then subjected to repeated sequences of stepped temperature treatments during which they were exposed for $18 \mathrm{~h}$ to $20^{\circ} \mathrm{C}$ and for $11.5 \mathrm{~h}$ to $15,10,7.5$ and $5{ }^{\circ} \mathrm{C}$, successively. Plant extension rates were measured mechanically by auxonometers attached to the youngest visible expanding leaf on a miscanthus plant. These auxonometers measured a combination of leaf and internodal extension. Leaf extension was estimated using ruler measurements of the leaf attached to the auxonometer. Leaf extension accounted for $83 \%$ of plant extension. The relationship between the temperature range and the plant extension rate fitted well with a third-order polynomial (Clifton-Brown and Jones, 1997). Farrell et al. (2006) determined the best fit relationship using an exponential regression model for the leaf extension rate (Tab. I).

From the model developed by Clifton-Brown and Jones (1997), the estimated ratio between expansion rates at $10{ }^{\circ} \mathrm{C}$ and $20{ }^{\circ} \mathrm{C}(\mathrm{Q} 10)$ varied among the genotypes and ranged from 3 to 4.7. All genotypes displayed predicted leaf extension at the lower temperature of $5{ }^{\circ} \mathrm{C}$ that was always less than $0.1 \mathrm{~mm} \cdot \mathrm{h}^{-1}$, except for two genotypes with a predicted rate of $0.19 \mathrm{~mm} . \mathrm{h}^{-1}$ and two others which had a leaf extension rate of $0.13 \mathrm{~mm} \cdot \mathrm{h}^{-1}$ (calculated from Clifton-Brown and Jones, 1997). However, these advantages at the lower temperature were lost at the higher temperature.

During the same experiment, simulation with a simple growth model showed that genotypes with lower threshold temperatures for leaf expansion were unlikely to display greater productivity than genotypes with more rapid expansion rates at temperatures higher than $10{ }^{\circ} \mathrm{C}$ (Clifton-Brown and Jones, 1997; Jorgensen and Muhs, 2001). Some genetic variability existed among genotypes with lower threshold temperatures for leaf expansion and others with a more rapid leaf extension rate when the air temperature was higher than $10^{\circ} \mathrm{C}$. Improved biomass yields could thus be expected if these two traits were combined at the optimum level.

\subsubsection{Effect on light interception and photosynthesis}

Final crop yields are closely linked to canopy photosynthesis during the growing season, which itself is dependent on the amount of radiation intercepted by leaves and the photosynthetic activity of individual leaves. Leaf area development and radiation-use efficiency have already been discussed in Sections 2.1 and 2.3 .

Weng and Ueng (1997) studied the optimum temperature for photosynthesis in Miscanthus in Taiwan and explained that it varied in line with habitats: it was higher than $35^{\circ} \mathrm{C}$ for lowland clones, which is close to the optimum temperature for maize and sugarcane (Yan and Hunt, 1999), but was $28^{\circ} \mathrm{C}$ for clones at altitudes above $2550 \mathrm{~m}$.

In contrast to related $\mathrm{C}_{4}$ species such as maize, $M$. giganteus displays a notable ability to maintain high photosynthetic productivity at low temperatures of $14{ }^{\circ} \mathrm{C}$ or $10{ }^{\circ} \mathrm{C}$ (Beale et al., 1996; Naidu et al., 2003; Farage et al., 2006). The molecular mechanism underlying this tolerance remains unclear. M. giganteus maintains a high rate of $\mathrm{CO}_{2}$ uptake in order to increase its utilisation of absorbed light (Beale et al., 
1996), and increases non-photochemical quenching (Farage et al., 2006) to prevent the marked reduction of $\mathrm{CO}_{2}$ assimilation observed in chilling-intolerant $\mathrm{C}_{4}$ species.

Nevertheless, the cold tolerance of $\mathrm{C}_{4}$ photosynthesis in M. giganteus may be related to the higher levels or activity of two major photosynthesis enzymes: Rubisco and Pyruvate Phosphate DiKinase (PPDK) (Sage and Kubien, 2007). Although no difference in Rubisco content and activity has been observed between $M$. giganteus plants grown under cold and warm conditions (Wang et al., 2008a), the rise in PPDK content and activity per unit leaf area in the cold-grown genotype was related to the recovery and maintenance of photosynthetic activity (Wang et al., 2008b). Naidu et al. (2003) found a $28 \%$ increase in PPDK levels in cold-grown miscanthus.

\subsection{Effect of frost}

Miscanthus may encounter two types of frost temperatures in Europe: negative temperatures during the winter and late frosts during the spring. The former may damage young plantings in Northern Europe and constitute an obstacle to crop establishment; in cooler areas, late frosts can damage newlyexpanded leaves during the first year of the crop or just after the regrowth of older plantings.

A capacity for winter survival has been described as the principal obstacle to the establishment of $M$. giganteus crops (Christian and Haase, 2001), particularly in Northern Europe (Denmark and Sweden), where no plants were able to regrow after the first winter (Lewandowski and Clifton-Brown et al., 2000). Similar mortality rates were observed in Ireland, the Netherlands, Belgium and Germany, as reported by Christian and Haase (2001). During these trials, plants started to grow during the spring after planting, but the first shoots produced were killed by late frosts and the rhizomes were unable to sprout again. The authors suggested that the winter survival of $M$. giganteus was mainly dependent on the generation of sufficient metabolic reserves in the rhizome system to enable the emergence of sufficient shoots the next spring (Christian and Haase, 2001; Schwarz et al., 1994).

Christian and Haase (2001) suggested that winter survival might also be related to dormancy during frosty periods: frost tolerance may only develop in these organs once dormancy has been induced during the autumn or early winter. Rhizomes and appending buds can be expected to have a higher frost tolerance than overwintering organs. However, a study on the frost tolerance of buds and rhizomes compared with that of leaves showed that this was not the case (Clifton-Brown and Lewandowski, 2000b; Jorgensen and Muhs, 2001; Farrell et al., 2006). This finding may have been due to the protection and isolation offered by the typical micro-structure of plant molecules and the surrounding soil, rather than to the inherent frost tolerance of rhizomes.

Plazek et al. (2009) tested the effects on metabolic activity and rhizome regrowth of exposing leaves to a frost of up to $-8{ }^{\circ} \mathrm{C}$ or $-15{ }^{\circ} \mathrm{C}$ following a 14-day acclimatisation period at $12{ }^{\circ} \mathrm{C}$ and a 21 -day period at $5{ }^{\circ} \mathrm{C}$. Although no frozen plants could produce new shoots, the rhizomes displayed some
Table II. Coincidence between the lowest lethal temperature $\left(\mathrm{LT}_{50}\right)$ and lowest moisture content (MC) of leaves and rhizomes in four genotypes of miscanthus but no correlation between $\mathrm{LT}_{50}$ of leaves and $\mathrm{LT}_{50}$ of rhizomes.

\begin{tabular}{|c|c|c|c|c|}
\hline & \multirow{2}{*}{\multicolumn{2}{|c|}{$\begin{array}{c}\text { Leaves } \\
\text { (Farrell et al., 2006) }\end{array}$}} & \multirow{2}{*}{\multicolumn{2}{|c|}{$\begin{array}{c}\text { Rhizomes } \\
\text { (Clifton-Brown and } \\
\text { Lewandowski, 2000b) }\end{array}$}} \\
\hline & & & & \\
\hline & $\mathrm{LT}_{50}\left({ }^{\circ} \mathrm{C}\right)$ & $\mathrm{MC}(\%)$ & $\mathrm{LT}_{50}\left({ }^{\circ} \mathrm{C}\right)$ & $\operatorname{MC}(\%)$ \\
\hline M. sacchariflorus & $-7.5 a b$ & $87 \mathrm{a}$ & $-3.5 b$ & $73 \mathrm{a}$ \\
\hline M. giganteus & $-8 \mathrm{~b}$ & $85 \mathrm{a}$ & $-3.5 \mathrm{~b}$ & $76 \mathrm{a}$ \\
\hline M. sinensis Hybrid 6 & $-6 a$ & $85 \mathrm{a}$ & $-6 \mathrm{a}$ & $68 \mathrm{~b}$ \\
\hline M. sinensis Hybrid 9 & $-9 \mathrm{c}$ & $80 \mathrm{~b}$ & $-4.5 a b$ & $71 \mathrm{~b}$ \\
\hline
\end{tabular}

$\mathrm{LT}_{50}$, the lethal temperature at which $50 \%$ of shoots (or rhizomes) were killed. MC, moisture content. Different letters indicate significant differences calculated from the least significant difference post-hoc $(P<0.05)$.

metabolic vitality after a 5 -week regrowth period at $20^{\circ} \mathrm{C}$. The authors concluded that frost susceptibility was due to the frost sensitivity of shoot apical meristems.

In terms of species variability, $M$. sinensis might be expected to be more frost-tolerant than $M$. sacchariflorus because in Asia, M. sacchariflorus is only found in warm regions, whereas $M$. sinensis is more ubiquitous (Clifton-Brown and Lewandowski, 2000b). Farrell et al. (2006) compared these species with $M$. giganteus in terms of cold tolerance at the shoot level (young shoots of 3-4 leaves). Their screening method consisted of growing plants in cabinets at $20+/-3{ }^{\circ} \mathrm{C}$ for 21 days with optimum supplies of water and nutrients. The plants were acclimatised at $12+/-2{ }^{\circ} \mathrm{C}$ for 8 days before their leaves were exposed to frost temperatures descending from $-2{ }^{\circ} \mathrm{C}$ to $-10{ }^{\circ} \mathrm{C}$ at a time-step of $2{ }^{\circ} \mathrm{C}$ every 3 hours. Before this frost treatment, leaves were sampled from each genotype to determine their moisture content. Any frost damage was assessed 7 days later. The lethal temperature at which $50 \%$ of the shoots were killed $\left(\mathrm{LT}_{50}\right)$ was estimated for each genotype. The same experiment was carried out on the same genotypes as those studied by Clifton-Brown and Lewandowski (2000b) in order to determine the $\mathrm{LT}_{50}$ of rhizomes.

$M$. sinensis hybrids were found to have significantly lower rhizome moisture contents than M. giganteus and M. sacchariflorus. These differences coincided with the lower $\mathrm{LT}_{50}$ of M. sinensis (Clifton-Brown and Lewandowski, 2000b; Farrell et al., 2006). Jorgensen et al. (2003b) found a higher rhizome moisture content in $M$. giganteus (none of which survived the first winter) than in $M$. sinensis and most $M$. sinensis hybrids which displayed survival rates of up to $85-99 \%$. However, the degree of resistance to negative temperatures differed in rhizomes and shoots. $M$. sinensis H6 had the lowest $\mathrm{LT}_{50}$ value for rhizomes while $M$. sinensis $\mathrm{H} 9$ had the lowest $\mathrm{LT}_{50}$ for shoots $\left(-6{ }^{\circ} \mathrm{C}\right.$ and $-9{ }^{\circ} \mathrm{C}$, respectively). Shoot and rhizome frost tolerance were not correlated in these studies (Tab. II). Tissue moisture content is considered to be one of the best characteristics for use during plant screening programmes with the accumulation of osmotically active 


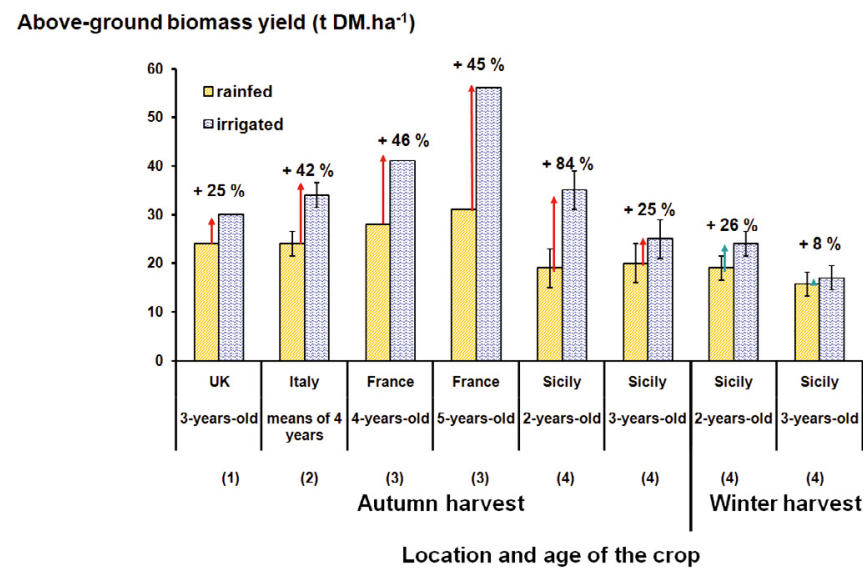

Figure 2. Increase in dry matter content of above-ground biomass under a water supply. Values taken from Beale and Long (1999) (1); Ercoli et al. (1999) (2); Cadoux et al. (2008) (3) and Cosentino et al. (2007) (4). The more marked difference in France was due to an interaction with nitrogen supply, where available, errors bars indicate $\operatorname{LSD}(P \leqslant 0.05)$.

compounds during cold acclimatisation (Lewitt, 1980). However, no correlations with frost tolerance were found for either leaves or rhizomes (Clifton-Brown and Lewandowski, 2000b; Farrell et al., 2006).

\subsection{Effect of water availability on biomass production and its components}

Increased productivity will result in higher water demand, so that water may become a limiting factor to both crop productivity and the economic viability of the crop. Because of the climatic differences between northern and southern Europe, it is therefore necessary to select potential energy crops from species with a high water-use efficiency (Long and Beale, 2001), particularly when adapting the species to water-limited areas. The identification of drought-tolerant genotypes that can produce more biomass under water stress conditions remains an essential component in the improvement of miscanthus (Clifton-Brown and Lewandowski, 2000a).

The effects of water availability in the field are described with respect to $M$. giganteus, particular in terms of biomass production and its components. The response of other Miscanthus species to water availability is then described under controlled conditions.

Irrigation exerts an important influence on yield when M. giganteus is grown at sites with a poor water supply (Christian and Haase, 2001). Heaton et al. (2004) described a highly significant effect of water availability on biomass production $(P<0.0001)$ in a review of several experiments throughout Europe. Under varying levels of nitrogen inputs (between 60 and $240 \mathrm{~kg} \mathrm{~N} \cdot \mathrm{ha}^{-1}$ ), biomass production increased by between $25 \%$ and $84 \%$ with irrigation (Fig. 2). The difference in yield between well-irrigated plots (100\% of evapotranspiration restored)) and less irrigated plots (25\% of evapotranspiration restored) was higher in autumn than in winter:
$+84 \%$ for an autumn harvest against $26 \%$ for a winter harvest (Fig. 2). Price et al. (2004) found similar losses of harvestable yield in the winter, of between $8 \%$ and $23 \%$, by using a potential yield model simulating limited water supplies in England and Wales. These marked differences between rainfed and irrigated yields could be related to the period during which the drought occurred. Richter et al. (2008) determined the main growing season as the period of susceptibility to drought in miscanthus.

In terms of biomass components, water availability does not affect shoot production (Christian and Haase, 2001; Cosentino et al., 2007; Cadoux et al., 2008). However, this lack of effect is probably because shoot production takes place during the period of high soil water availability (at the beginning of the growing period). By contrast, the number of stems is more closely dependent on planting densities than on irrigation rate, i.e. water availability.

Plant height is not influenced by water availability at the beginning of the growing period. Nevertheless, a reduction in water availability towards the end of the growing period was found to markedly influence plant height (Christian and Haase, 2001; Cosentino et al., 2007; Cadoux et al., 2008). Irrigated plants were $49 \%$ taller than those without irrigation. A similar trend was observed for the leaf area index (Cosentino et al., 2007; Cadoux et al., 2008). Irrigation caused a 77\% increase in the leaf area index compared with no irrigation. However, this effect was not reported by Christian and Haase (2001). In Miscanthus giganteus, Cosentino et al. (2007) also observed a one month difference in the flowering date between irrigated and rainfed treatments.

During studies to compare $M$. giganteus, $M$. sinensis and $M$. sacchariflorus under controlled conditions, a reduction in leaf area was observed in M. giganteus and M. sacchariflorus but not in $M$. sinensis under water stress (Clifton-Brown and Lewandowski, 2000a; Clifton-Brown et al., 2002). However, the leaf area of $M$. sinensis was smaller before the water stress was applied. Furthermore, the water needs of this species may be less than in the other species. The authors concluded that $M$. sinensis might be less sensitive to water stress. In addition, M. sacchariflorus and M. giganteus presented an increase in the senescence of green leaf area, while $M$. sinensis presented a lack of senescence under all treatments. This experiment suggested that the "stay green" mechanism in M. sinensis may be related to stomatal closure with a low soil moisture content. No data are available on the variability of the "stay green" mechanism observed in species of $M$. sinensis.

Photosynthetic activity contributes to adapting miscanthus to drought. Weng (1993) showed that both stomatal and nonstomatal photosynthesis factors were affected by water deficit, and suggested that genotypes displaying the highest degree of osmotic adjustment (OA) were the best at maintaining photosynthetic activity under water deficit. Nevertheless, no differences in OA were observed among $M$. sinensis, $M$. sacchariflorus and $M$. giganteus under severe water deficit, although M. sinensis was more tolerant to water stress (Clifton-Brown et al., 2002). Leaf conductance was markedly reduced in $M$. sinensis, even under mild water stress, so that a completely green leaf area was maintained throughout the experiment. 
Table III. Higher increase in plant height or above-ground dry biomass of $M$. giganteus for plots with water supply ( $\left.\mathrm{I}_{2}\right)$ and nitrogen supply $\left(\mathrm{N}_{1}, \mathrm{~N}_{2}\right.$ or $\mathrm{N}_{3}$ ) than for plots with nitrogen supply only. Data taken from Cosentino et al. (2007) (1) and Ercoli et al. (1999) (2).

\begin{tabular}{|c|c|c|c|c|c|}
\hline & & \multicolumn{2}{|c|}{ Water supply (mm) } & \multirow{2}{*}{$\begin{array}{c}\text { Plant height } \\
+2 \%\end{array}$} & \multirow{2}{*}{$\begin{array}{c}\begin{array}{c}\text { Above-ground } \\
\text { dry biomass }\end{array} \\
+21 \%\end{array}$} \\
\hline 2 years old & $\begin{array}{l}\mathrm{I}_{0} \mathrm{~N}_{0} \\
\mathrm{I}_{0} \mathrm{~N}_{2}\end{array}$ & $272 \mathrm{~mm}$ & \multirow{2}{*}{$+244 \%$} & & \\
\hline (1) & $\begin{array}{l}\mathrm{I}_{2} \mathrm{~N}_{0} \\
\mathrm{I}_{2} \mathrm{~N}_{2}\end{array}$ & $938 \mathrm{~mm}$ & & $+22 \%$ & $+39 \%$ \\
\hline \multirow{2}{*}{$\begin{array}{l}3 \text { years old } \\
\text { (1) }\end{array}$} & $\begin{array}{l}\mathrm{I}_{0} \mathrm{~N}_{0} \\
\mathrm{I}_{0} \mathrm{~N}_{2} \\
\end{array}$ & $228 \mathrm{~mm}$ & \multirow{2}{*}{$+93 \%$} & $+47 \%$ & $+8 \%$ \\
\hline & $\begin{array}{l}\mathrm{I}_{2} \mathrm{~N}_{0} \\
\mathrm{I}_{2} \mathrm{~N}_{2} \\
\end{array}$ & $439 \mathrm{~mm}$ & & $+53 \%$ & $+25 \%$ \\
\hline \multirow{2}{*}{$\begin{array}{c}\text { Means of } 4 \text { years } \\
\text { (2) }\end{array}$} & $\begin{array}{l}\mathrm{I}_{0} \mathrm{~N}_{0} \\
\mathrm{I}_{0} \mathrm{~N}_{1} \\
\end{array}$ & $228 \mathrm{~mm}$ & \multirow{2}{*}{$+100 \%$} & & $+23 \%$ \\
\hline & $\begin{array}{l}\mathrm{I}_{2} \mathrm{~N}_{0} \\
\mathrm{I}_{2} \mathrm{~N}_{1}\end{array}$ & $439 \mathrm{~mm}$ & & & $+41 \%$ \\
\hline \multirow{2}{*}{$\begin{array}{c}\text { Means of } 4 \text { years } \\
\text { (2) }\end{array}$} & $\begin{array}{l}\mathrm{I}_{0} \mathrm{~N}_{0} \\
\mathrm{I}_{0} \mathrm{~N}_{3} \\
\end{array}$ & $228 \mathrm{~mm}$ & \multirow{2}{*}{$+100 \%$} & & $+41 \%$ \\
\hline & $\begin{array}{l}\mathrm{I}_{2} \mathrm{~N}_{0} \\
\mathrm{I}_{2} \mathrm{~N}_{3}\end{array}$ & $439 \mathrm{~mm}$ & & & $+100 \%$ \\
\hline
\end{tabular}

$\mathrm{I}_{0}$, rainfall; $\mathrm{I}_{2}$, Irrigation.

$\mathrm{N}_{0}, \mathrm{~N}_{\text {soil }} ; \mathrm{N}_{1}, \mathrm{~N}_{\text {soil }}+100 \mathrm{~kg} \mathrm{~N} \cdot \mathrm{ha}^{-1} ; \mathrm{N}_{2}, \mathrm{~N}_{\text {soil }}+120 \mathrm{~kg} \mathrm{~N} \cdot \mathrm{ha}^{-1} ; \mathrm{N}_{3}, \mathrm{~N}_{\text {soil }}+200 \mathrm{~kg} \mathrm{~N} \cdot \mathrm{ha}^{-1}$.

\subsection{Effect of nitrogen availability on biomass and its components}

Plant growth and development are dependent on nitrogen availability. Nitrogen forms part of living cells and is essential to all protein, enzymatic and metabolic processes involved in synthesis and transfer to energy. The response of biomass production and its components to nitrogen supply has been the subject of more study in $M$. giganteus species (Ercoli et al., 1999; Christian and Haase, 2001; Cosentino et al., 2007; Danalatos et al., 2007; Christian et al., 2008) than in M. sinensis species (Obara, 1967; Matsumura et al., 1975; Sato et al., 1975 and Hoshimo, 1978 cited by Stewart, 2009).

Obara (1967), Matsumura et al. (1975), Sato et al. (1975) and Hoshimo (1978) cited by Stewart et al. (2009) showed that nitrogen is one of the most important nutrients required to increase the biomass production of $M$. sinensis grassland. A N input level of around $100 \mathrm{~kg} \mathrm{~N} \cdot \mathrm{ha}^{-1}$ can achieve a $50 \%$ to $500 \%$ higher biomass yield, and affect biomass components. Hoshimo (1978) observed a 16\%-33\% increase in plant height and leaf size under appropriate nitrogen supply.

By contrast, under non-limiting water conditions, nitrogen fertiliser rates of between 60 and $240 \mathrm{~kg} \mathrm{~N} . \mathrm{ha}^{-1}$ generally had little or no effect on the biomass yield, stem number, plant height and leaf area index of $M$. giganteus species (Ercoli et al., 1999; Christian and Haase, 2001; Danalatos et al., 2007; Cadoux et al., 2008; Christian et al., 2008).

During a multi-environment experiment, Lewandowski and Schmidt (2006) observed a trend towards increased biomass yields with a $\mathrm{N}$ input level of about $110 \mathrm{~kg} \mathrm{~N} . \mathrm{ha}^{-1}$, followed by a slight decline. However, these results varied considerably, as the same biomass of about $35 \mathrm{t}^{\mathrm{h} \mathrm{h}^{-1}}$ could be produced with nitrogen inputs ranging from 90 to $150 \mathrm{~kg} \mathrm{~N}^{-h^{-1}}{ }^{-}$. This variability might have been explained by the soil nitrogen supply, but these data were not available.

In a Mediterranean environment but with a water supply, Cosentino et al. (2007) found an autumn biomass yield that was $21 \%$ higher $\left(120 \mathrm{~kg} \mathrm{~N} \mathrm{ha}^{-1}\right)$ than without nitrogen during the second year of the crop. This increase even reached $35 \%$ for a winter harvest. It could be attributed to an $11 \%$ increase in plant height and a $27 \%$ increase in stem numbers par square metre.

Plant responses to nitrogen depend on the water available for biomass production. During the same experiment, Cosentino et al. (2007) determined a marked nitrogen effect when the crop received less water during its third year of growth (Tab. III). During an extended period of water stress in July, plant height was $53 \%$ higher under nitrogen input, but the difference was smaller $(22 \%)$ when water was abundant during the second year of growth. The nitrogen effect also appears to be dependent on crop age, as a weak effect of nitrogen was only observed in two- or three-year-old crops (Cosentino et al., 2007; Lewandowski and Schmidt, 2006). Contrary to what was expected, no nitrogen effect was detected when the crop was mature and after 14 successive spring harvests (Lewandowski et al., 2000; Danalatos et al., 2007; Christian et al., 2008). No data are available on the effect of successive autumn harvests, and it could be expected that these might increase crop nitrogen requirements; the allocation of nitrogen from leaves and stems to rhizomes occurs during the winter.

According to these results, $M . \times$ giganteus has low nitrogen needs for growth. For example, Long and Beale (2001) found that $93 \mathrm{~kg}$ of $\mathrm{N}$ availability per hectare enabled the production of $25 \mathrm{t}_{\text {.ha }}{ }^{-1}$ of above-ground biomass. Nevertheless, Beale and Long (1997) recommended nitrogen input of between 50 and $90 \mathrm{~kg} \cdot \mathrm{ha}^{-1} \cdot$ year $^{-1}$ to enable rhizome development and prevent soil exhaustion. 
Moreover, Beale et al. (1996) reported no difference in the photosynthetic potential of $M$. giganteus under either $120 \mathrm{~kg}(\mathrm{~N}) \cdot \mathrm{ha}^{-1}$ or no nitrogen applications under temperate field conditions. Weng and Hsu (2001) showed that the photosynthetic capacity of seventeen Miscanthus clones collected from lowland areas in northern and southern Taiwan and mountainous areas in central Taiwan increased slightly with $\mathrm{N}$ applications from $8-16 \mu \mathrm{mol} \cdot \mathrm{m}^{-2} \cdot \mathrm{s}^{-1}$ with no nitrogen input to $12-21 \mu \mathrm{mol} \cdot \mathrm{m}^{-2} \cdot \mathrm{s}^{-1}$ under $176 \mathrm{~kg} \cdot \mathrm{ha}^{-1}$ nitrogen. However, no correlation with biomass production was calculated during this study.

This low need for and response to nitrogen of $M . \times g i$ ganteus crops, even after 14 years of winter harvest, could be attributed to efficient nitrogen storage by the rhizome. By studying ${ }^{15} \mathrm{~N}$-amended soil, Christian et al. (1997) found that plant nitrogen uptake over 2 years was greater than the amount supplied as fertiliser and arising from soil nitrogen. The plants were thus able to obtain nitrogen from other sources. Eckert et al. (2001) identified one of these as a nitrogenfixing bacterium, Azospirillium, associated with the roots of M. giganteus. Another study found the same type of bacterium (Clostridia) associated with the roots of M. sinensis (Miyamoto et al., 2004) and its stems (Ye et al., 2005). No studies have yet been performed to determine the relationships and exchanges between miscanthus roots and these bacteria, but Ye et al. (2005) showed that the inoculation of this type of bacteria in biomass enhanced the tolerance of salinity. It is therefore possible that exchanges between bacteria and miscanthus exist. Moreover, Funatsu (2006) cited by Stewart et al. (2009) reported that AM fungi (Arbuscular mycorrhiza) associated with the roots of $M$. sinensis in volcanic and ashy soil might enhance nitrogen assimilation.

\section{CONCLUSIONS AND PROSPECTS}

Miscanthus has been identified as a good candidate for biomass production. Peak yields of $49 \mathrm{t} \mathrm{DM} \cdot \mathrm{ha}^{-1}$ have been observed in Europe during an autumn harvest of mature crops with irrigation. We observed smaller maximum yields of between 7 and $26 \mathrm{tDM}_{\mathrm{DMa}}{ }^{-1}$ for a winter harvest, this difference mainly being due to leaf loss. Because of its $\mathrm{C}_{4}$ photosynthetic pathway and perennial rhizome, $M . \times$ giganteus displays a satisfactory combination of radiation-, water- and nitrogen-use efficiencies (see Sect. 2.3) when compared with several other bio-energy crops.

The slight effect of nitrogen input on yield increases under water stress. However, lower levels of nitrogen availability need to be tested in the future because soil nitrogen availability and mineralisation have not been addressed by most studies, suggesting that experiments have probably been carried out under nitrogen excess to demonstrate any effect in miscanthus.

The high potential for above-ground biomass production by $M$. giganteus, and the efficiencies of this crop, nonetheless varied under different management systems and climates. Two key elements for improvement have been identified by the present review. Firstly, frost tolerance during the winter or early spring seems essential in northern Europe in order to ensure overwintering and protect young shoots after early emergence. Although M. giganteus has been identified as a $\mathrm{C}_{4}$ cold-tolerant species by comparison with maize because of its higher PPDK protein content at cold temperatures, we did not observe any winter survival of $M$. giganteus in northern Europe (north Sweden and Denmark). Susceptibility to winter frost at temperatures below $-3.5^{\circ} \mathrm{C}$ for the rhizome and $-8{ }^{\circ} \mathrm{C}$ for young shoots of $M$. $\times$ giganteus may lead to marked plant losses and lower yields. Secondly, water supply is necessary to ensure a good establishment rate and a high biomass yield. We observed a reduction of up to $84 \%$ in above-ground dry matter production under water stress for autumn harvests, and up to $26 \%$ for winter harvests. This reduction was mainly due to a $49 \%$ decrease in plant height and a 77\% decrease in leaf area index. Insofar as a lack of water will become a crucial problem in some areas in the decades to come, it is essential to improve the tolerance of miscanthus to water stress and the water-use efficiency of this crop under diverse levels of water supply.

Because no genetic variability exists in $M$. giganteus, and because the development of a single clone of this species throughout Europe might facilitate disease development, $M$. sinensis must provide the genetic resources for frost and water stress tolerance. Through the production of hybrids, this species displays a good potential for biomass yield under European conditions, as well as tolerance to frost and to limited water supplies. Firstly, its better frost tolerance than M. giganteus has been observed in hybrids between two M. sinensis which have been able to resist temperatures as low as $-6{ }^{\circ} \mathrm{C}$ for rhizomes and $-9^{\circ} \mathrm{C}$ for young shoots. And secondly, M. sinensis is able to maintain its leaf area index under water stress during the first stage of growth, even though it has a similar water-use efficiency.

However, to date it has not been possible to combine a high tolerance of abiotic stress with high levels of biomass production. It is now necessary either to identify $M$. sinensis genotypes that can produce an above-ground biomass yield close to that of M. giganteus under water stress and/or low growth temperatures, or to generate new interspecific hybrids of $M$. giganteus with higher tolerance thresholds. On a crop scale, the cultivation of sterile species, for example with unpaired ploidy levels, would be useful to prevent uncontrolled invasion. As in other genera, this variation in genome ploidy could lead to variations in species traits, particularly with respect to biomass production, but no studies have as yet been reported.

Acknowledgements: The authors acknowledge the Picardie region (project PEL), which supported this work. We thank Prof. A. Gallais for his helpful comments on the manuscript. Thanks also to the anonymous reviewers for their valuable recommendations.

\section{REFERENCES}

Angelini L.G., Ceccarini L., Di Nasso N.N., Bonari E. (2009) Comparison of Arundo donax L. and Miscanthus $\times$ giganteus in a long-term field experiment in Central Italy: Analysis of productive characteristics and energy balance, Biomass Bioenerg. 33, 635643. 
Aspinal D. (1961). The control of tillering in the barley plant I. The pattern of tillering and its relation to nutrient supply, Aust. J. Biol. Sci. $14,93-505$

Beale C.V., Long S.P. (1995) Can perennial C 4 grasses attain high efficiencies of radiant energy-conversion in cool climates, Plant Cell Environ. 18, 641-650.

Beale C.V., Long S.P. (1997) Seasonal dynamics of nutrient accumulation and partitioning in the perennial C-4-grasses Miscanthus $\times$ Giganteus and Spartina Cynosuroides, Biomass Bioenerg. 12, 419428 .

Beale C.V., Bint D.A., Long S.P. (1996) Leaf photosynthesis in the $\mathrm{C}_{4}$ grass Miscanthus $\times$ giganteus, growing in the cool temperate climate of southern England, J. Exp. Bot. 47, 267-273.

Beale C.V., Morison J.I.L., Long S.P. (1999) Water use efficiency of $\mathrm{C}_{4}$ perennial grasses in a temperate climate, Agr. Forest Meteorol. 96, $103-115$.

Benbi D.K., Brar J.S. (2009) A 25-year record of carbon sequestration and soil porperties in intensive agriculture, Agron. Sustain. Dev. 29, 257-265.

Boehmel C., Lewandowski I., Claupein W. (2008) Comparing annual and perennial energy cropping systems with different management intensities, Agr. Syst. 96, 224-236.

Bullard M.J., Nixon P.M.I., Cheath M. (1997) Quantifying the yield of Miscanthus $\times$ giganteus in the UK, Aspects Appl. Biol. 49, 199206.

Cadoux S., Vanderdriessche V., Machet J.M., Mary B., Beaudouin N., Lemaire G., Gosse G. (2008) Potential yield and main limiting factors of Miscanthus giganteus in France. Identification of the needs for further research, in: 16th European Biomass Conference and Exhibition, Valence.

Ceotto E. (2008) Grasslands for bioenergy production. A review, Agron, Sustain. Dev. 28, 47-55.

Christian D.G., Haase E. (2001) Agronomy of Miscanthus, in: Jones M., Walsh M. (Eds.), Miscanthus for energy and fibre, James and James, London, UK, pp. 21-45.

Christian D.G., Poulton P.R., Riche A.B., Yates N.E. (1997) The recovery of ${ }^{15} \mathrm{~N}$-labelled fertilizer applied to Miscanthus $\times$ giganteus, Biomass Bioenerg. 12, 21-24.

Christian D.G., Poulton P.R., Riche A.B., Yates N.E., Todd A.D. (2006) The recovery over several seasons of $15 \mathrm{~N}$-labelled fertilizer applied to Miscanthus $\times$ giganteus ranging from 1 to 3 years old, Biomass Bioenerg. 30, 125-133.

Christian D.G., Riche A.B., Yates N.E. (2008) Growth, yield and mineral content of Miscanthus $\times$ giganteus grown as a biofuel for 14 succissive harvests, Ind. Crop. Prod. 28, 320-327.

Christian D.G., Yates N.E., Riche A.B. (2009) Estimation of ramet production from Miscanthus $\times$ giganteus rhizome of different ages, Ind. Crop. Prod. 30, 176-178.

Clifton-Brown J.C., Jones M.B. (1997) The thermal response of leaf extension rate in genotypes of the $\mathrm{C}_{4}$-grassMiscanthus: an important factor in determining the potential productivity of different genotypes, J. Exp. Bot. 48, 1573-1581.

Clifton-Brown J.C., Lewandowski I. (2000a) Water Use Efficiency and Biomass Partitioning of Three Different Miscanthus Genotypes with Limited and Unlimited Water Supply, Ann. Bot. 86, 191-200.

Clifton-Brown J.C., Lewandowski I. (2000b) Overwintering problems of newly established Miscanthus plantations can be overcome by identifying genotypes with improved rhizome cold tolerance, New Phytol. 148, 287-294
Clifton-Brown J.C., Lewandowski I. (2002). Screening Miscanthus genotypes in field trials to optimise biomass yield and quality in Southern Germany, Eur. J. Agron. 16, 97-100.

Clifton-Brown J.C., Lewandowski I., Andersson B., Basch G., Christian D.G., Kjeldsen J.B., Jorgensen U., Mortensen J.V., Riche A.B., Sshwarz K.U., Tatebe K., Teixeira F. (2001a) Performance of 15 Miscanthus genotypes at five sites in Europe, Agron. J. 93, 10131019.

Clifton-Brown J.C., Lewandowski I., Bangerth F., Jones M.B. (2002) Comparative responses to water stress in stay-green, rapid- and slow senescing genotypes of the biomass crop, Miscanthus, New Phytol. 154, 335-345.

Clifton-Brown J.C., Long S.P., Jorgensen U. (2001b) Miscanthus productivity, in: Jones M., Walsh M. (Eds.), Miscanthus for energy and fibre, James and James, London, UK, pp. 46-67.

Clifton-Brown J.C., Neilson B., Lewandowski I., Jones M.B. (2000) The modelled productivity of Miscanthus $\times$ giganteus (GREEF et DEU) in Ireland, Ind. Crop. Prod. 12, 191-200.

Clifton-Brown J.C., Stampfl P.F., Jones M.B. (2004) Miscanthus biomass production for energy in Europe and its potential contribution to decreasing fossil fuel carbon emissions, Global Change Biol. 10, $509-518$

Cosentino S.L., Patane C., Sanzone E., Copani V., Foti S. (2007) Effects of soil water content and nitrogen supply on the productivity of Miscanthus $\times$ giganteus Greef et Deu. in a Mediterranean environment, Ind. Crop. Prod. 25, 75-88.

Crutzen P.J., Mosier A.R., Smith K.A., Winiwarter W. (2008) $\mathrm{N}_{2} \mathrm{O}$ release from agro-biofuel production negates global warming reduction by replacing fossil fuels, Atmos. Chem. Phys. 8, 389-395.

Danalatos N.G., Archontoulis S.V., Mitsios I. (2007) Potential growth and biomass productivity of Miscanthus $\times$ giganteus as affected by plant density and $\mathrm{N}$-fertilization in central Greece, Biomass Bioenerg. 31, $145-152$.

DEFRA (2007) Planting and growing Miscanthus, Best practice guidelines, For Applicants to DEFRA's Energy Crops Scheme.

Deuter M. (2000) Breeding approaches to improvement of yield and quality in Miscanthus grown in Europe, EMI Project, Final report, pp. $28-52$.

Eckert B., Weber O.B., Gudrun K., Andras H., Marion S., Anton H. (2001) Azospirillum doebereinerae sp. nov., a nitrogen-fixing bacterium associated with the $\mathrm{C}_{4}$ - grass Miscanthus, Int. J. Syst. Evol. Microbiol. 51, 17-26.

Ercoli L., Mariotti M., Masoni A., Bonari E. (1999) Effect of irrigation and nitrogen fertilization on biomass yield and efficiency of energy use in crop production of Miscanthus, Field Crop. Res. 63, 3-11.

Farage P., Blowers D., Long S.P., Baker N.R. (2006). Low growth temperature modify the efficiency of light use by photosystem II for $\mathrm{CO}_{2}$ assimilation in leaves of two chilling tolerant $\mathrm{C}_{4}$ species, Cyperus longus L. and Miscanthus $\times$ giganteus, Plant Cell Environ. 29, 720728 .

Farrell A.D., Clifton-Brown J.C., Lewandowski I., Jones M.B. (2006) Genotypic variation in cold tolerance influences the yield of Miscanthus, Ann. Appl. Biol. 149, 337-345.

Gillet M. (1980) Les graminées fourragères, Gauthiers-Villars, 306 p.

Greef J.M., Deuter M. (1993) Syntaxonomy of Miscanthus-X-Giganteus Greef-Et-Deu, Angew. Bot. 67, 87-90.

Greef J.M., Deuter M., Jung C., Schondelmaier J. (1997) Genetic diversity of European Miscanthus species revealed by AFLP fingerprinting, Genet. Resour. Crop Ev. 44, 185-195. 
Gurtler J. (2007) Biocarburants 2010 : Quelles utilisations des terres en France ? Ed ONIGC.

Hansen E.M., Christensen B.T., Jensen L.S., Kristensen K. (2004) Carbon sequestration in soil beneath long-term Miscanthus plantations as determined by ${ }^{13} \mathrm{C}$ abundance, Biomass Bioenerg. 26, 97-105.

Hastings A., Clifton-Brown J.C., Wattenbach M., Stampfl P., Mitchell C.P., Smith P. (2008) Potential of Miscanthus grasses to provide energy and hence reduce greenhouse gas emissions, Agron. Sustain. Dev. 28, 465-472.

Heaton E.A., Clifton-Brown J., Voigt T.B., Jones M.B., Long S.P. (2004) Miscanthus for renewable energy generation: European Union experience and projections for Illinois, Mitigation and Adaptation Strategies for Global Change 9, 21-30.

Heaton E.A., Dohleman, F.G., Long S.P. (2008) Meeting US biofuel goals with less land: the potential of Miscanthus, Global Change Biol. 14, 2000-2014.

Himken M., Lammel J., Neukirchen D., Czypionka-Krause U., Olfs H.W. (1997) Cultivation of Miscanthus under West European conditions: Seasonal changes in dry matter production, nutrient uptake and remobilization, Plant Soil 189, 117-126.

Hodkinson T.R., Chase M.W., Renvoize S.A. (2002) Characterization of a genetic resource collection for Miscanthus (Saccharinae, Andropogoneae, Poaceae) using AFLP and ISSR PCR, Ann. Bot. $89,627-636$.

Jezowski S. (2008) Yield traits of six clones of Miscanthus in the first 3 years following planting in Poland, Ind. Crop. Prod. 27, 65-68.

Jorgensen U., Muhs H. (2001) Miscanthus: Breeding and Improvement, in: Jones M., Walsh M. (Eds.), Miscanthus for energy and fibre, James and James, London, UK, pp. 68-85.

Jorgensen U., Mortensen J., Ohlsson C. (2003a) Light interception and dry matter conversion efficiency of miscanthus genotypes estimated from spectral reflectance measurements, New Phytol. 157, 263 270.

Jorgensen U., Mortensen J., Kjeldsen J.B., Schwarz K.U. (2003b) Establishment, Developement and yield qualoty of fifteen Miscanthus genotypes over three years in Denmark, Acta Agr. Scand. B. S. P. 53, 190-199.

Kalembasa D., Je£owski S., Pude R., Malinowska E. (2005) The content of carbon, hydrogen and nitrogen in different development stage of some clones of Miscanthus, Pol. J. Soil Sci. 38, 169-177.

Lewandowski I. (1998) Propagation method as an important factor in the growth and development of Miscanthus $\times$ giganteus, Ind. Crop. Prod. 8, 229-245.

Lewandowski I. Clifton-Brown J.C. (2000) European Miscanthus Improvement Project (EMI), FAIR3 CT-96-1392, Final Report, $260 \mathrm{p}$.

Lewandowski I., Kauter D. (2003) The influence of nitrogen fertilizer on the yield and combustion quality of whole grain crops for solid fuel use, Ind. Crop. Prod. 17, 103-117.

Lewandowski I., Kicherer A. (1997) Combustion quality of biomass: Practical relevance and experiments to modify the biomass quality of Miscanthus $\times$ giganteus, Eur. J. Agron. 6, 163-177.

Lewandowski I., Schmidt U. (2006) Nitrogen, energy and land use efficiencies of miscanthus, reed canary grass and triticale as determined by the boundary line approach, Agr. Ecosyst. Environ. 112, 335-346.

Lewandowski I., Clifton-Brown J.C., Scurlock J.M.O., Huisman W. (2000) Miscanthus: European experience with a novel energy crop, Biomass Bioenerg. 19.
Lewandowski I., Kicherer A., Vonier P. (1995) $\mathrm{Co}_{2}$-Balance for the Cultivation and Combustion of Miscanthus, Biomass Bioenerg. 8, 81-90.

Lewandowski I., Scurlock J.M.O., Lindvall E., Christou M. (2003) The development and current status of perennial rhizomatous grasses as energy crops in the US and Europe, Biomass Bioenerg. 25, 335361.

Lewitt J. (1980) Responses of Plants to Environmental Stresses, Vol. 1, Academic Press, New York, pp. 87-90.

Linde-Laursen I. (1993) Cytogenetic analysis of Miscanthus 'Giganteus', an interspecific hybrid, Hereditas 119, 297-300.

Long S.P., Beale C.V. (2001) Resource Capture by Miscanthus, in: Jones M., Walsh M. (Eds.), Miscanthus for energy and fibre, James and James, London, UK, pp. 10-20.

Miyamoto T., Kawahar, M., Minalisawa K. (2004) Novel Endophytic Nitrogen-fixing Clostridia from grass Miscanthus sinensis as reveled by terminal restriction fragment lenght polymorphism analysis, Appl. Environ. Microbiol. 70, 6580-6586.

Naidu S.L., Moose S.P., Al-Shoaibi A.K., Raines C.A., Long S.P. (2003) Cold tolerance of $\mathrm{C}_{4}$ photosynthesis in Miscanthus $\times$ giganteus: Adaptation in amounts and sequence of $\mathrm{C}_{4}$ photosynthetic enzymes, Plant Physiol. 132, 1688-1697.

Plazek A., Dubert F., Marzec K. (2009) Cell membrane permeability and antioxidant activities in the rootstocks of Miscanthus $\times$ giganteus as an effect of cold and frost treatment, J. Appl. Bot. Food Quality $82,158-162$.

Price L., Bullard M.J., Lyons H., Anthony S., Nixon P.M.I. (2004) Identifying the yield potential of Miscanthus $\times$ giganteus: an assessment of the spatial and temporal variability of $\mathrm{M} . \times$ giganteus biomass productivity across England and Wales, Biomass Bioenerg. 26, 3-13.

Ritchter G.M., Riche A.B., Dailey A.G., Gezan S.A., Powlson D.S. (2008) Is UK biofuel supply from Miscanthus water-limited? Soil Use Manage. 24, 235-245.

Sage R.F, Kubien D.S. (2007) The temperature response of $\mathrm{C}_{3}$ and $\mathrm{C}_{4}$ photosynthesis, Plant Cell Environ. 30, 1086-1106.

Schwarz K.U, Murphy D.P.L., Schnug E. (1994) Studies of the growth and yield of Miscanthus $\times$ giganteus in Germany, Aspects Appl. Biol. 40, 533-540.

Shoji S., Kurebayashi T., Yamada I. (1990) Growth and chemical composition of Japanese pampas grass (Miscanthus sinensis) with special reference to the formation of dark-colored andisols in northeastern Japan, Soil Sci. Plant Nutr. 36, 105-120.

Stewart J.R., Toma Y., Fernandez F.G., Nishiwaki A., Yamada T., Bollero G. (2009) The ecology and agronomy of Miscanthus sinensis, a species important to bioenergy crop development, in its native range in Japan: a review, Global Change Biol. 1, 126-153.

Tayot X., Chartier M., Varlet-Grancher C., Lemaire G. (1995) Potential above-ground dry matter production of miscanthus in north-central France compared to sweet sorghum, in: Chartier P., Beenackers A., Grassi G. (Eds.), Biomass for energy, environment, agriculture and industry, Elsevier, Oxford, UK, pp. 556-564.

Thorne G.N. (1962) Survival of tillers and distribution of dry matter between ear and shoot of barley varieties, Ann. Bot. 26, 37-54.

Vargas L.A., Andersen M.N., Jensen C.R., Jorgensen U. (2002) Estimation of leaf area index, light interception and biomass accumulation of Miscanthus sinensis 'Goliath' from radiation measurements, Biomass Bioenerg. 22, 1-14.

Vonwuhlisch G., Deuter M., Muhs H.J. (1994) Identification of Miscanthus Varieties by Their Isozymes, J. Agron. Crop Sci. 172, $247-254$. 
Walsh M. (1998) Miscanthus handbook. Miscanthus productivity Network AIR-CT92-0294, Hyperion Energy Systems Ltd, Cork, Ireland, p. 225.

Wang D., Naidu S., Portis A.R., Moose S.P., Long S.P. (2008a) Can the cold tolerance of $\mathrm{C}_{4}$ photosynthesis in Miscanthus $\times$ giganteus relative to Zea mays be explained by differences in activities and thermal properties of Rubisco, J. Exp. Bot. 59, 1779-1787.

Wang D., Portis A.R., Moose S.P., Long S.P. (2008b) Cool C $\mathrm{C}_{4}$ Photosynthesis: Pyruvate $\mathrm{P}_{i}$ Dikinase Expression and Activity Corresponds to the Expectional Cold Tolerance of Carbon Assimilation in Miscanthus $\times$ giganteus, Plant Physiol. 148, 557567.

Wang M., Wu M., Huo H. (2007) Lice- cycle energy and greenhouse gas emission impacts of differents corn ethanol plant types, Environ. Res. Lett. 2, 1-13.
Weng J.-H. (1993) Photosynthesis of different ecotypes of Miscanthus spp. as affected by water stress, Photosynthetica 29, 43-48.

Weng J.H., Hsu F.-H. (2001) Gas Exchange and Epidermal Characteristics of Miscanthus Populations in Taiwan Varying with Habitats and Nitrogen Application, Photosynthetica 39, 35-41

Weng J.H., Ueng R.G. (1997) Effect of temperature on photosynthesis of Miscanthus clones collected from different elevations, Photosynthetica 34, 307-311.

Yan W.K., Hunt L.A. (1999). An equation for modelling the temperature response of plant using only the cardinal temperature, Ann. Bot. 84, 607-614.

Ye B., Saito A., Minamisawa K. (2005) Effect of inoculation with anaerobic nitrogen-fixing consortium on salt tolerance of Miscanthus sinensis, Soil Sci. Plant Nutr. 51, 243-249. 